The Underside of Politics 
This page intentionally left blank 


\section{The Underside of Politics}

Global Fictions in the Fog of the Cold War

SORIN RADU CUCU

Fordham University Press

NEW YORK 2013 


\section{Copyright (C) 2013 Fordham University Press}

All rights reserved. No part of this publication may be reproduced, stored in a retrieval system, or transmitted in any form or by any means-electronic, mechanical, photocopy, recording, or any other-except for brief quotations in printed reviews, without the prior permission of the publisher.

Fordham University Press has no responsibility for the persistence or accuracy of URLs for external or third-party Internet websites referred to in this publication and does not guarantee that any content on such websites is, or will remain, accurate or appropriate.

Fordham University Press also publishes its books in a variety of electronic formats. Some content that appears in print may not be available in electronic books.

\section{Library of Congress Cataloging-in-Publication Data}

Cucu, Sorin Radu.

The underside of politics : global fictions in the fog of the Cold War / Sorin Radu Cucu.

pages ; $\mathrm{cm}$

Includes bibliographical references and index.

ISBN 978-0-8232-5434-7 (cloth : alk. paper)

1. Fiction-2oth century-History and criticism. 2. Cold War in literature.

3. Political fiction-History and criticism. 4. National characteristics in literature. 5. Cold War-Social aspects-Europe. I. Title.

PN3448.P6C83 2013

$809.3 ' 935809045-\mathrm{dc} 23$

2013006704

Printed in the United States of America

$\begin{array}{llllllll}15 & 14 & 13 & 5 & 4 & 3 & 2 & 1\end{array}$

First edition

A book in the American Literatures Initiative (ALI), a collaborative publishing project of NYU Press, Fordham University Press, Rutgers University Press, Temple University Press, and the University of Virginia Press. The Initiative is supported by The Andrew W. Mellon Foundation. For more information, please visit www.americanliteratures.org. 
To my grandfather, Radu Necula 
This page intentionally left blank 